\title{
Karakteristik Vertikal Salinitas dan TDS di Perairan Amed dan Tulamben, Karangasem, Bali
}

\author{
Gede Indra Putra Pratama ${ }^{a}$, I Gede Hendrawan ${ }^{a^{*}}$, I Wayan Gede Astawa Karang ${ }^{a}$, Alexis Chappuis ${ }^{b}$ \\ ${ }^{a}$ Program Studi Ilmu Kelautan, Fakultas Kelautan dan Perikanan, Universitas Udayana, Bali, Indonesia \\ ${ }^{b}$ Underwater Scientific Exploration and Education (UNSEEN) Expeditions \\ *Corresponding author email : gede.hendrawan@unud.ac.id
}

\section{ARTICLE INFO}

\section{Article history:}

Received: November $01^{\text {th }} 2019$

Received in revised form: November $29^{\text {th }} 2019$

Accepted: February $05^{\text {th }} 2020$

Available online: February $28^{\text {th }} 2020$
Keywords:

Salinity

$T D S$

Temporal

Vertical

Amed and Tulamben

\section{ABSTRACT}

Amed and Tulamben waters are marine tourism areas located in the western part of the Lombok Strait, which have enormous biodiversity and conservation potential. The abundant biodiversity in the area is because of the process of transporting water masses vertically carrying biogenic and non-biogenic components. Salinity and TDS have an important role in regulating the process of bio-geo-chemical waters. Thus, it can be a parameter in understanding the vertical characteristics of the waters. The purpose of this research was to determine the vertical characteristics of temporal salinity and TDS in these waters. Data was collected for 14 days (February 20 to March 5, 2019) at two locations, namely Batu Niti and Emerald. The data collection method was carried out by reducing the CTD to a depth of approximately 95 meters with a measurement interval of 10 minutes for 2 to 3 hours per day. The results showed that salinity and TDS had a very strong correlation $(\mathrm{r}=0.9995)$. Salinity concentrations ranged from 31.83 to 34.19 PSS, and TDS concentrations ranged from $31,211.12$ to $33,396.71 \mathrm{mg} \mathrm{l}^{-1}$. The halocline layer had a gradient characteristic $\geq 0.01 \mathrm{PSS} \mathrm{m}^{-1}$ found from a depth of 20 meters, while a homogeneous layer was formed above it to a depth of 6 meters. The halocline layer had a higher level of water mass stability $(\mathrm{N})$ than the homogeneous layer. The maximum rate of change in salinity and TDS was found at a depth of 70 meters. The great variability of salinity and TDS in the water column was indicated by the influence of internal tidal currents. Before the highest tide conditions, salinity and TDS have highest variability that compared to the highest tide condition and after its condition.

2020 JMRT. All rights reserved.

\section{Pendahuluan}

Perairan Indonesia memiliki karakteristik hidrografi yang sangat beragam, diantaranya banyak ditemukan topografi dasar laut yang kasar (sill/ambang), melewati celah-celah sempit (selat), pasang surut yang kuat, pengaruh atmosfer (angin musim), dan penghubung jalur sirkulasi conveyor belt kemudian dikenal dengan Indonesian Throughflow (Atmadipoera et al., 2009; Rosenfield et al., 2010). Selat Lombok menjadi salah satu jalur utama Indonesian Throughflow (ITF) yang berperan penting dalam integrasi sirkulasi termohalin global, berdampak langsung pada massa air kolam (basin), transfer panas, serta persediaan air tawar antara Samudera Pasifik dan Samudera Hindia (Wajsowicz and Schneider, 2001; Matthews et al., 2011). Selain sebagai jalur utama ITF, terdapat ambang laut pemisah Pulau Nusa Penida dan Pulau Lombok mengakibatkan aliran pasang-surut yang kuat dan tingginya turbulensi vertikal perairan (Aiki et al., 2011).

Perairan Kabupaten Karangasem khususnya Kawasan Wisata Bahari Amed dan Tulamben merupakan salah satu perairan di bagian barat Selat Lombok yang memiliki tingkat kesuburan perairan dan potensi konservasi yang tinggi (Mustika et al., 2012). Kawasan tersebut memiliki kelimpahan jenis karang dan ikan karang yang tinggi, serta menjadi habitat bagi spesies penting seperti ikan Mola-mola, beberapa jenis hiu, penyu laut, dan juga ikan Napoleon (Mustika et al., 2012). Sebagai gambaran, sebanyak 181 spesies karang dari 406 spesies yang ditemukan di Bali terdapat di perairan Jemeluk (Turak and DeVantier, 2009), dan sebanyak 230 spesies ikan karang ditemukan di perairan Kepa (Allen, 2007).

Beberapa komponen kimia perairan laut yang digunakan sebagai parameter kualitas perairan diantaranya yaitu salinitas dan Total Dissolved Solids (TDS). Salinitas berperan penting dalam proses biologis perairan yaitu sebagai aspek laju pertumbuhan, jumlah nutrisi yang di konsumsi, dan kelangsungan hidup organisme perairan (Andrianto, 2005 in Amri et al., 2018). Selain itu, salinitas juga berperan dalam persebaran organisme dan oksigen di perairan (Nurhayati, 2006 in Valdi et al., 2012; Patty, 2013). Perubahan salinitas dapat mengganggu keseimbangan biodiversitas biota laut, memunculkan spesies yang kurang toleran, dan menyebabkan toksisitas yang tinggi pada tahapan hidup suatu organisme (Weber-Scannell and Duffy, 2007). TDS didefinisikan sebagai jumlah zat padat baik berupa ion-ion organik, senyawa, maupun koloid yang terlarut dalam air (WHO, 2003). Perubahan konsentrasi TDS dapat menyebabkan perubahan salinitas, komposisi ion-ion dalam perairan, dan toksisitas yang muncul dari masing-masing ion (Rinawati et al., 2016).

Keanekaragaman hayati dan kesuburan perairan Amed dan Tulamben disebabkan oleh proses pencampuran masa air secara vertikal, yang akan membawa komponen biogenik dan non- 
biogenik dalam kolom perairan (Weidemann et al., 1996; Mustika et al., 2012). Penelitian sebelumnya yang dilakukan oleh Karang et al. (2010), menjelaskan bahwa jalur keluar ITF yang diwakili perairan Indonesia bagian selatan yaitu Selat Lombok dan Timor Passage memiliki konversi energi pasang-surut barotropik ke baroklinik (internal) dan diapycnal mixing yang tinggi yaitu masing-masing sebesar $26,7 \mathrm{GW}$ dan $10 \times 10^{-4} \mathrm{~m}^{2} \mathrm{~s}^{-1}$, sehingga berpotensi meningkatkan proses pencampuran vertikal massa air sekitar perairan. Proses pencampuran vertikal massa air dibatasi oleh sistem pelapisan kolom perairan yang berkaitan erat dengan tingkat stabilitas massa air (Pond and Pickard, 1983). Pelapisan kolom perairan memiliki sifat yang dinamis, hal ini dipengaruhi oleh energi pembangkit arus, kedalaman perairan, kondisi batimetri, upwelling dan downwelling, material padatan tersuspensi, posisi lintang, curah hujan, serta variabilitas iklim grobal (Tomczak, 2000; Tang et al., 2006). Sifat dinamis kolom perairan akan membentuk karakteristik vertikal suatu perairan, kemudian dapat dipahami melalui berbagai parameter oseanografi diantaranya salinitas dan TDS yang berperan penting dalam mengatur proses biogeokimia perairan (Marwan et al., 2015). Karakteristik internal Selat Lombok khususnya pada bagian jalur utama ITF sudah banyak dilakukan kajian oleh peneliti-peneliti sebelumnya (Susanto et al., 2005; Mitnik, 2006; Purba and Utami, 2006; Ningsih et al., 2008; Hendrawan and Asai 2011; Karang et al., 2012; Harvianto et al., 2015), namun masih sedikit dilakukan pada wilayah pesisir. Oleh karena itu, penelitian mengenai karakteristik vertikal perairan Amed dan Tulamben menjadi penting dilakukan, mengingat besar potensi bahari pada kawasan tersebut tidak terlepas dari faktor oseanografi khususnya salinitas dan TDS yang dibahas pada penelitian ini.

\section{Metode Penelitian}

\subsection{Waktu dan Lokasi Penelitian}

Penelitian ini dilaksanakan selama kurang lebih enam bulan (Februari-Juli 2019) meliputi proses persiapan, pengambilan data, dan analisis data. Pengambilan data dilaksanakan selama 14 hari pada tanggal 20 Februari - 5 Maret 2019, dengan lokasi penelitian di perairan Kawasan Wisata Bahari Amed-Tulamben. Penelitian yang tergabung dalam rangkaian proyek dari Underwater Scientific Exploration and Education (UNSEEN). Titik pengamatan mengikuti agenda dari proyek UNSEEN yang melakukan kegiatan penyelaman hingga kedalaman 100 meter pada dua lokasi yaitu Batu Niti sebagai stasiun utama dan Emerald yang berjarak $\pm 3 \mathrm{~km}$ ke arah barat laut sebagai stasiun control (Gambar 1).

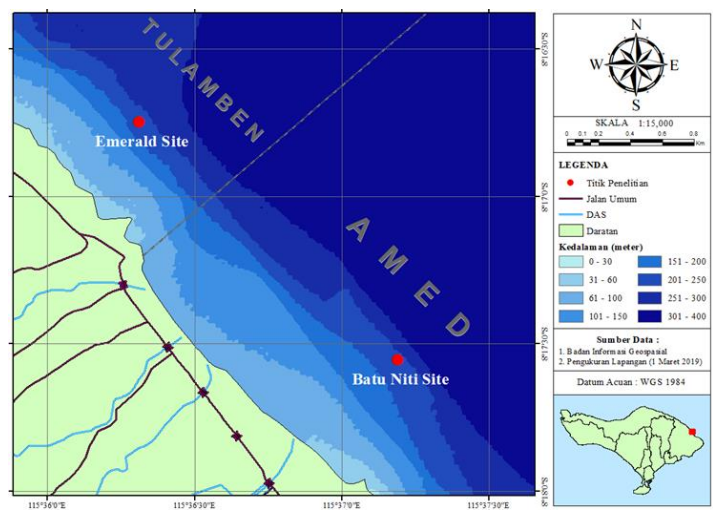

Gambar 1. Lokasi penelitian

2.2. Penentuan Titik Pengamatan
Uji coba kedalaman perairan dilakukan dengan menurunkan langsung CTD (Conductivity Temperature Depth), apabila tali yang digunakan menurunkan CTD masih tersisa pada rope rollers (sudah menyentuh dasar perairan), maka dilakukan kembali penurunan CTD pada lokasi yang lebih jauh dari pantai hingga tali tidak tersisa dan menegang, kemudian dilakukan proses tagging pada GPS sebagai titik penelitian. Titik pengamatan di kawasan Batu Niti berjarak $\pm 400 \mathrm{~m}$ dari lokasi penyelaman dengan koordinat $8.29258^{\circ} \mathrm{LS}$; $115.619861^{\circ} \mathrm{BT}$, sedangkan titik pengamatan di kawasan Emerald berjarak \pm 200 meter dari lokasi penyelaman dengan koordinat $8.279115^{\circ} \mathrm{LS}$; $115.605189^{\circ}$ BT. Kedalaman perairan pada titik pengamatan, kemudian divalidasi dengan hasil pengukuran batimetri tanggal 1 Maret 2019 menggunakan Echosounder, dimana kedalaman perairan sekitar 151-200 meter.

\subsection{Pengambilan Data CTD}

Pengambilan data CTD pada stasiun utama (Batu Niti) dilakukan selama 11 hari yaitu pada tanggal 20, 21, 23, 25, 27, 28 Februari 2019, dan tanggal 1-5 Maret 2019, sedangkan 3 hari sisanya yaitu tanggal 22, 24, dan 26 Februari 2019 dilakukan pada stasiun kontrol (Emerald). Pengambilan data CTD dilakukan setiap 10 menit selama 2-3 jam tiap hari (menyesuaikan dengan lama waktu penyelaman). Pengambilan data CTD dengan interval waktu tiap 10 menit merupakan perkiraan waktu yang ideal dalam menurunkan dan menaikkan CTD hingga kedalaman $\pm 95 \mathrm{~m}$.

\subsection{Analisis Data}

\subsubsection{Penyederhanaan Nilai Salinitas dan Konduktivitas}

Data yang diperoleh dari hasil pengukuran CTD terdistribusi secara acak dan sangat kompleks, sehingga diperlukan penyederhanaan nilai kedalaman tiap interval 1 meter dalam upaya mempermudah tahap analisis selanjutnya. Nilai yang dilakukan penyederhanaan yaitu salinitas dan konduktivitas disimbolkan dengan electrical conductivity (EC) pada CastAwayCTD. Adapun persamaan yang digunakan sesuai dengan Emery dan Thomson (1997) disajikan pada persamaan 1:

$$
P_{n}=P_{n-1}-\frac{\left(h_{n-1}-h_{n}\right)\left(P_{n-1}-P_{n+1}\right)}{\left(h_{n-1}-h_{n+1}\right)}
$$

dimana, $P_{n}$ adalah nilai salinitas dan konduktivitas yang dicari; $P_{n-1}$ adalah nilai salinitas dan konduktivitas kedalaman bagian atas; $P_{n+1}$ adalah nilai salinitas dan konduktivitas kedalaman bagian bawah; $h_{n}$ adalah kedalaman yang dicari; $h_{n-1}$ adalah kedalaman bagian atas; $h_{n+1}$ adalah kedalaman bagian bawah.

\subsubsection{Penentuan Nilai TDS}

Nilai TDS dapat ditentukan dari data penyederhanaan nilai electrical conductivity (EC), semakin besar nilai EC perairan mengindikasikan semakin banyak mineral terkandung dalam air (Effendi, 2003), dimana erat kaitannya dengan TDS yang sering dijadikan sebagai parameter kualitas air. Hubungan TDS dan EC ditunjukkan pada persamaan 2 (Hem, 1970 in Pradhan and Pirasteh, 2011).

$$
T D S=0,7 \times E C
$$

\subsubsection{Uji Statistik Korelasi Regresi Sederhana}

Analisis korelasi regresi sederhana digunakan untuk mempelajari dan mengukur hubungan statistik yang terjadi antara dua variabel yaitu salinitas dan TDS. Persamaan regresi 
sederhana menurut Sudjana (1992) ditunjukkan pada persamaan 3 dan 4.

$$
\begin{aligned}
& Y^{\prime}=a+b X \\
& a=\frac{\left(\sum y\right)\left(\sum x^{2}\right)-\left(\sum x\right)\left(\sum x y\right)}{n\left(\sum x^{2}\right)-\left(\sum x\right)^{2}} ; b=\frac{n\left(\sum x y\right)-\left(\sum x\right)\left(\sum y\right)}{n\left(\sum x^{2}\right)-\left(\sum x\right)^{2}}
\end{aligned}
$$

dimana, $Y^{\prime}$ adalah nilai variabel dependen (terikat $\sim$ TDS); $X$ adalah nilai variabel independen (bebas $\sim$ salinitas); $a$ adalah konstanta atau titik potong garis regresi pada sumbu y (nilai $Y^{\prime}$ bila $X=0) ; b$ adalah koefisien atau gradien garis regresi (perubahan nilai $Y^{\prime}$ per satuan perubahan nilai $X$ ).

Adapun perhitungan korelasi sederhana menurut Harianti et al. (2012) adalah sebagai berikut.

$$
r=\frac{\sum x y-\frac{\left(\sum x\right)\left(\sum y\right)}{n}}{\sqrt{\left(\sum x^{2}-\frac{\left(\sum x\right)^{2}}{n}\right)\left(\sum y^{2}-\frac{(\Sigma y)^{2}}{n}\right)}}
$$

dimana, $r$ adalah koefisien korelasi; $x$ adalah nilai variabel independen (bebas salinitas); $y$ adalah nilai variabel dependen (terikat TDS); kisaran nilai korelasi: $-1<r<+1$. Makna koefisien kisaran nilai korelasi tersebut ditunjukkan pada Tabel 1.

Tabel 1. Tingkat hubungan koefisien korelasi

\begin{tabular}{ll}
\hline Koefisien Korelasi & Hubungan \\
\hline $0-0,199$ & Korelasi sangat lemah \\
$0,20-0,399$ & Korelasi lemah \\
$0,40-0,599$ & Korelasi sedang \\
$0,60-0,799$ & Korelasi kuat \\
$0,80-1,0$ & Korelasi sangat kuat \\
\hline
\end{tabular}

Sumber: (Sugiyono, 2008)

\subsubsection{Analisis Gradien Konsentrasi Salinitas dan TDS serta Stabilitas Massa Air}

Gradien secara umum didefinisikan sebagai nilai yang menyatakan kemiringan suatu persamaan garis lurus $\left(m=\frac{\Delta y}{\Delta x}\right)$. Analisis gradien dalam bidang oseanografi umum dilakukan untuk mengetahui gradien tekanan, temperatur, dan gradien konsentrasi gas terlarut pada persamaan Hukum Fick (Tanaka et al., 1999; Millero, 2013). Pada penelitian ini, analisis gradien dilakukan untuk mengetahui kecepatan perubahan konsentrasi salinitas dan TDS berdasarkan perubahan kedalaman. Persamaan gradien konsentrasi salinitas dan TDS ditunjukkan pada persamaan 6.

$$
m_{\text {Sal,TDS }}=\frac{\Delta C_{\text {SalTDS }}}{\Delta h_{\text {SaITDS }}}
$$

dimana, $m_{\text {Sal,TDS }}$ adalah gradien konsentrasi salinitas (PSS $\mathrm{m}^{-1}$ ) dan TDS $\left(\mathrm{mg} / \mathrm{l} \mathrm{m}^{-1}\right) ; \Delta C_{\text {Sal,TDS }}$ adalah perubahan konsentrasi salinitas dan TDS; $\Delta h_{\text {Sal,TDS }}$ adalah perubahan kedalaman (m).

Perbedaan gradien tiap perubahan kedalaman menandakan bahwa karakteristik massa air selalu berubah secara vertikal. Pada waktu tertentu lapisan perairan mengalami ganguan akibat faktor internal maupun internal, yang akan menyebabkan massa air menjadi tidak stabil (densitas tinggi di atas densitas rendah). Pickard dan Emery (1990), memaparkan bahwa gaya gravitas dan buoyancy mengakibatkan massa air yang tidak stabil akan berosilasi atau bergerak vertikal kembali menuju posisi stabil. Stabilitas massa air dapat ditentukan dengan menghitung nilai frekuensi daya apung atau Brunt-Väisälä $(N)$ pada tiap kedalaman $i$ sebagai berikut (Park et al., 2008) (persamaan 7).

$$
N_{i}=\left(-\frac{g}{\rho_{0}} \frac{d \rho}{d z}\right)^{1 / 2}
$$

dimana, $\rho_{o}$ adalah background densitas perairan yang diperoleh dari rata-rata densitas kedalaman 0 - 95 meter; $d \rho$ adalah gradien densitas terhadap perubahan kedalaman $d z$ (1 meter); dan $g$ adalah percepatan gravitasi bumi $\left(9,79423 \mathrm{~m} / \mathrm{s}^{2}\right)$.

Angin merupakan faktor eksternal perairan (atmosfer) yang sangat mempengaruhi profil perairan secara vertikal dan tingkat stabilitas massa air di permukaan (Stewart, 2009; Santos-Garcia et al., 2014). Pergerakan arus permukaan yang meningkat dipicu oleh kecepatan angin sehingga terjadi pencampuran massa air (Kunarso et al., 2011). Data angin diperoleh dari data sekunder yaitu hasil perkiraan model atmosfer European Center for Medium-Range Weather Forecasts (ECMWF). Model perkiraan kecepatan angin ECMWF menghasilkan komponen angin $U$ (komponen kecepatan angin dengan arah timur-barat) dan $V$ (komponen kecepatan angin dengan arah utara-selatan). Resolusi data $0,125^{\circ} \times 0,125^{\circ}$ atau resolusi terkecil digunakan dengan maksud memperoleh data angin lebih detail dan mendekati titik lokasi penelitian, sehingga diperoleh data angin dengan koodinat $8.25^{\circ} \mathrm{LS} ; 115.625^{\circ} \mathrm{BT}$. Resultan kecepatan angin pada koordinat tersebut dihitung dengan persamaan 8 (Corsin, 2007 in Kusuma and Sulistiya, 2018).

$$
\bar{v}=\sqrt{U^{2}+V^{2}}
$$

\subsubsection{Analisis Laju Perubahan Konsentrasi Salinitas dan TDS}

Laju perubahan didefinisikan adanya perpindahan atau perubahan suatu variabel terhadap satuan waktu, kemudian sering dikenal sebagai kecepatan (v). Analisis laju perubahan salinitas dan TDS dapat dilakukan pada data yang diambil secara temporal seperti pada penelitian ini. Data salinitas dan TDS yang dianalisis yaitu tiap interval kedalaman $5 \mathrm{~m}(0,5,10,15,20 \mathrm{~m}$ dan seterusnya). Besar perpindahan atau perubahan suatu variabel dari satu titik ke titik lain dapat ditentukan dengan nilai mutlak (Karso, 1997). Nilai mutlak yang dimaksud adalah selisih nilai salinitas dan TDS antara dua waktu pengambilan data pada kedalaman yang sama, dengan persamaan sebagai berikut.

$$
|\Delta x|=x_{t 2}-x_{t 1}
$$

Laju perubahan konsentrasi salinitas dan TDS $\left(\bar{v}_{\text {min }}\right)$ dapat ditentukan dengan persamaan sebagai berikut (Tjondro and Tanti, 2009).

$\bar{v}_{\min }=\frac{\Sigma|\Delta x|}{\Delta t_{\min }}$

dimana, $\Sigma|\Delta x|$ adalah jumlah nilai mutlak salinitas dan TDS; dan $\Delta t_{\text {min }}$ adalah rentang waktu pengambilan data per-hari (menit).

Satuan baku internasional untuk waktu adalah detik (Page and Vigoureux, 1975), maka hasil laju perubahan dikonversikan kedalam satuan per-sekon (persamaan 11).

$\bar{v}_{\sec }=\bar{v}_{\min } \times \frac{1}{60}$ 


\subsubsection{Analisis Konsentrasi Salinitas dan TDS berdasarkan Kondisi Pasang-Surut}

Proses interpolasi data elevasi pasang-surut Oritide dibutuhkan untuk menyesuaikan dengan waktu interval pengambilan data CTD. Metode interpolasi non-linier spline digunakan dengan bantuan sistem aplikasi MATLAB R2016 (persamaan 12) (Sahid, 2005).

$S(x)=\left\{\begin{aligned} S_{1}(x) & \text { untuk } x_{1} \leq x \leq x_{2} \\ S_{2}(x) & \text { untuk } x_{2} \leq x \leq x_{3} \\ S_{n-1}(x) & \text { untuk } x_{n-1} \leq x \leq x_{n}\end{aligned}\right.$

Nilai-nilai elevasi hasil interpolasi non-linier spline kemudian dikelompokkan berdasarkan kondisi pasang-surut, dimana dipilih 5 data CTD dengan interval pengambilan 10 menit untuk mewakili kondisi pasang-surut tertentu, dan selisih waktu antara kondisi pasang-surut satu dengan lainnya adalah 60 menit. Data salinitas dan TDS yang dihasilkan dari interval pengambilan data CTD dalam kondisi pasang-surut tertentu memungkinkan adanya persebaran data yang umumnya dikenal simpangan baku atau standar deviasi (persamaan 13) (Soewarno, 1995).

$$
S_{x}=\sqrt{\frac{\sum_{i=1}^{n}\left(x_{i}-\bar{x}\right)^{2}}{n-1}}
$$

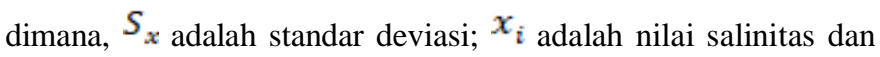
TDS; $\bar{x}$ adalah nilai rata-rata; $n$ adalah jumlah data.

\section{Hasil dan Pembahasan}

\subsection{Hubungan Salinitas dan TDS}

Uji statistik korelasi dan regresi sederhana dilakukan pada 20.506 pasang data dari hasil penyederhanaan nilai salinitas dan TDS. Grafik hubungan korelasi regresi salinitas ( $x$ ) dan TDS $(y)$ (Gambar 2), menggambarkan jelas hubungan positif antara salinitas dan TDS di perairan Amed dan Tulamben, dapat dilihat dari hasil koefisien korelasi bernilai positif yaitu 0,9995 dan apabila dikaitkan pada tabel tingkat hubungan koefisien korelasi Sugiyono (2008), tergolong memiliki hubungan korelasi yang sangat kuat. Koefisien determinasi juga dapat digunakan untuk menunjukkan keterkairan antar variabel dengan persamaan $r^{2}$ (Hastono, 2006). Nilai koefisien determinan diperoleh 0,9989 yang menunjukkan kemampuan salinitas mempengaruhi TDS ataupun sebaliknya sebesar $99,89 \%$, sedangkan sisanya dipengaruhi oleh faktor lain $(0,11 \%)$. Persamaan regresi $Y^{\prime}=2538,5+900,2 X$, memiliki nilai konstanta (a) 2538,5 menunjukkan besarnya variabel TDS yang tidak dipengaruhi oleh salinitas, serta koefisien regresi 900,2 menjelaskan bahwa setiap peningkatan 1 satuan nilai salinitas akan meningkatkan 900,2 satuan nilai TDS, begitu juga sebaliknya apabila terjadi penurunan nilai salinitas.

Hubungan korelasi yang sangat kuat antara salinitas dan TDS dikarenakan dasar perhitungan kedua parameter tersebut berasal dari karakteristik konduktivitas perairan, baik secara langsung melalui sensor elektroda CTD maupun dihasilkan melalui sistem persamaan rasio jenis air (Miller et al., 1988; Wagner et al., 2006). Rusydi (2018) menjelaskan bahwa konduktivitas (EC) dan padatan terlarut total (TDS) merupakan parameter kualitas air yang digunakan untuk menggambarkan tingkat salinitas perairan. Penelitian sebelumnya juga menjelaskan, dalam sampel air murni (natural water) dengan rasio perairan 0,55 - 0,75 (rasio air laut $0,7)$ memiliki nilai TDS yang berbanding lurus dengan salinitas, sedangkan nilai TDS dalam wastewater atau perairan tercemar berbanding lurus dengan bahan organik yang terlarut seperti hidrokarbon dan urea (Thompson, 2006; Clescerl et al., 1998 in Choo-in, 2019).

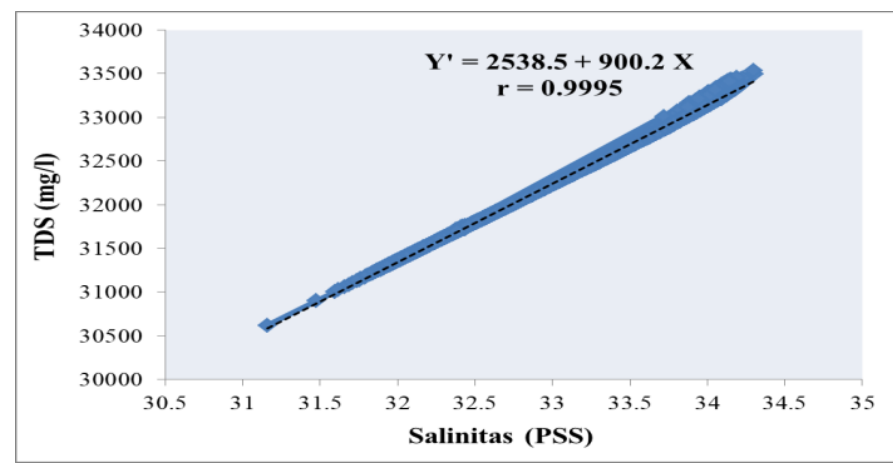

Gambar 2. Grafik hubungan salinitas dan TDS di perairan Amed dan Tulamben menggunakan uji statistik korelasi dan regresi

\subsection{Gradien Konsentrasi Salinitas dan TDS serta Stabilitas Massa Air}

Hasil penyederhanaan nilai pengukuran CTD yang dilakukan selama 14 hari dengan kedalaman rata-rata tiap pengukuran 95 meter, diperoleh kisaran salinitas 31,83 - 34,19 PSS, dan kisaran TDS 31.211,12 - 33.394,71 $\mathrm{mg} \mathrm{l}^{-1}$. Lapisan haloklin (gradien salinitas $\geq 0,01 \mathrm{PSS} / \mathrm{m}$; Lukas and Lindstrom, 1991) ditemukan terbentuk dari kedalaman $20 \mathrm{~m}$. Fluktuasi (naik/turun) nilai gradien pada lapisan tersebut membentuk empat pola dari kedalaman $34-93 \mathrm{~m}$. Gradien salinitas dan TDS terus mengalami peningkatan hingga kedalaman $37 \mathrm{~m}$, sedikit mengalami penurunan hingga kedalaman $41 \mathrm{~m}$, kembali meningkat hingga $5 \mathrm{~m}$ kebawah, kemudian menurun kembali hingga kedalaman $56 \mathrm{~m}$. Pada kedalaman 57 - $71 \mathrm{~m}$ relatif mengalami peningkatan nilai gradien, setelah itu penurunan nilai kembali ditemukan hingga kedalaman 84 m, 6 m kebawah relatif mengalami peningkatan dan kembali menurun hingga kedalaman $93 \mathrm{~m}$. Nilai gradien tergolong tinggi (>0,025 PSS $/ \mathrm{m} ; 20 \mathrm{mg} \mathrm{l}^{-}$ $1 / \mathrm{m}$ ) ditemukan pada kisaran kedalaman 35 - $95 \mathrm{~m}$. Lapisan homogen (gradien salinitas < 0,01 PSS/m; Lukas and Lindstrom, 1991) ditemukan pada kedalaman dekat permukaan yaitu $6-19$ m. Gradien konsentrasi salinitas dan TDS yang relatif tinggi $\left(0,015-0,05 \mathrm{PSS} / \mathrm{m} ; 14-45 \mathrm{mg} \mathrm{l}^{-1} / \mathrm{m}\right)$ juga ditemukan hingga 5 $\mathrm{m}$ di bawah permukaan perairan, hal tersebut diindikasikan adanya distorsi pengukuran CTD akibat pengadukan balingbaling mesin perahu dan/atau hasil interaksi gelombang permukaan dengan lambung perahu (Gargett and Garner, 2008). Profil gradien konsentrasi salinitas dan TDS di perairan Amed dan Tulamben dapat dilihat pada (Gambar 3).

Angin musim (munson) menjadi faktor penting dalam dinamika perairan Selat Lombok secara vertikal, indikasi upwelling pada musim barat (Desember - Februari) menyebabkan lapisan homogen menjadi lebih tipis sehingga mendorong ke atas lapisan haloklin yang berada di bawahnya, dan terjadi sebaliknya pada musim timur (Delcroix and McPhaden, 2002; Purba and Utami, 2006). Susanto et al. (2007), menjelaskan lebih rinci mengenai kedalaman lapisan termohalin (lapisan dengan gradien suhu dan salinitas tinggi) di Selat Lombok berkisar dari kedalaman 25 - 130 m pada musim barat, sedangkan pada musim timur berkisar dari kedalaman 50 - $135 \mathrm{~m}$. Penelitian yang dilakukan oleh Hamzah and Trenggono (2014), yang melakukan pengukuran profil vertikal perairan di beberapa titik yang mewakili bagian utara, tengah, dan selatan Selat Lombok menghasilkan bahwa lapisan haloklin mulai ditemukan sekitar kedalaman 20 - 30 m. Menurut Harvianto et al. (2015), 
kedalaman perairan juga berdampak pada struktur vertikal perairan, dimana semakin dangkal kedalaman perairan akan menyebabkan lapisan termohalin semakin terdorong ke atas sehingga lapisan homogen semakin tipis, namun masih perlu dilakukan pengambilan data pembanding (in-situ) dengan instrumen yang sama untuk membuktikan hal tersebut.

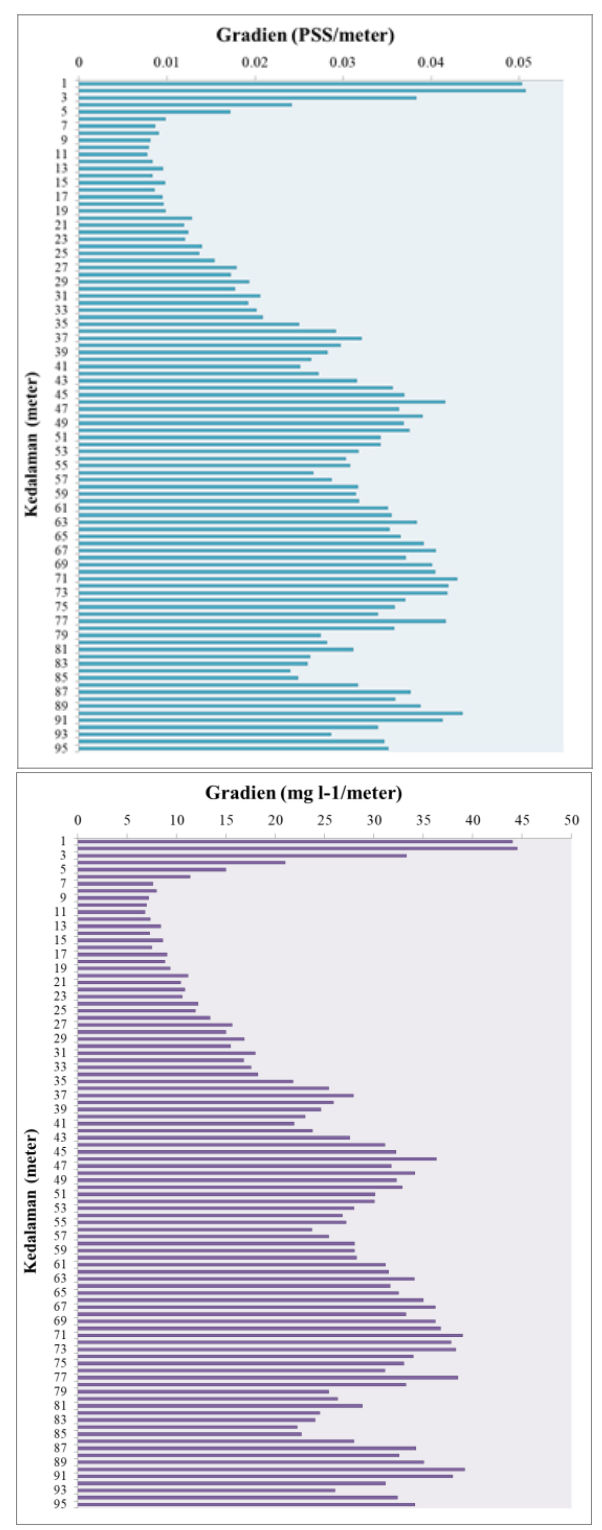

Gambar 3. Profil gradien konsentrasi salinitas (atas) dan TDS (bawah) di perairan Amed dan Tulamben

Hasil perhitungan frekuensi Brunt-Väisälä $(N)$ rata-rata pada (Gambar 4) menunjukkan adanya kecenderungan tingkat stabilitas massa air relatif tinggi pada permukaan perairan $(37,2 \mathrm{x}$ $\left.10^{-5} \mathrm{~s}^{-1}\right)$, kemudian mengalami penurunan pada lapisan homogen (nilai $N$ minimum $6,14 \times 10^{-5} \mathrm{~s}^{-1}$ pada kedalaman $11 \mathrm{~m}$ ). Apabila dikaitkan dengan kedalaman lapisan haloklin pada (Gambar 3), tingkat stabilitas perairan tertinggi ditemukan pada lapisan tersebut (nilai $N$ maksimum 46,6 x $10^{-5} \mathrm{~s}^{-1}$ pada kedalaman 77 m). Pond dan Pickard (1983), menjelaskan bahwa gradien salinitas dan temperatur sangat menentukan tingkat stabilitas lapisan perairan, dimana semakin tinggi gradien maka semakin tinggi nilai $N$ lapisan tersebut. Hasil ini sesuai dengan penelitian yang dilakukan di Selat Ombai oleh Suteja et al. (2015), dimana tingkat stabilitas massa air tertinggi ditemukan pada lapisan termohalin dengan rata-rata nilai $N 14,8 \times 10^{-3} \mathrm{~s}^{-1}$ sedangkan terendah ditemukan pada lapisan homogen dengan rata-rata nilai $N 1,6 \times 10^{-3} \mathrm{~s}^{-1}$. Menurut Graff dan Menden-Deuer (2016), Lapisan dengan stabilitas yang lebih tinggi mengandung konsentrasi fitopankton tinggi, selanjutnya akan meningkatkan produktivitas primer lapisan tersebut.

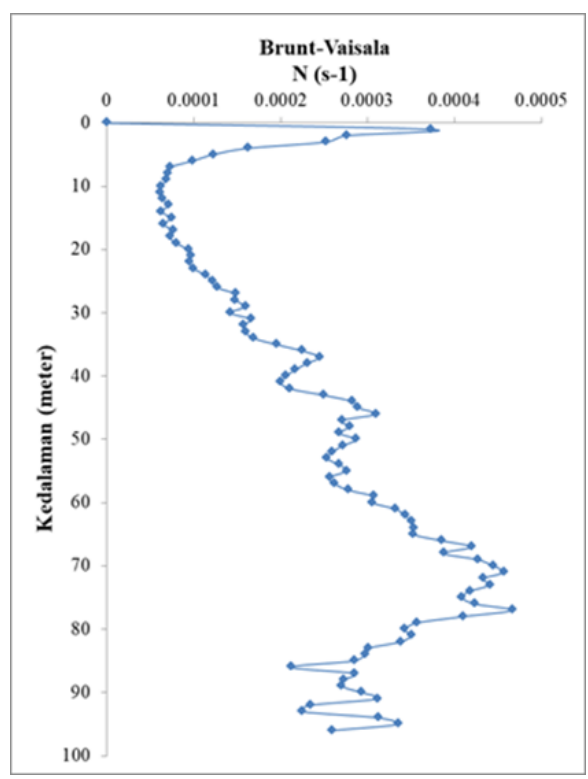

Gambar 4. Frekuensi Brunt-Väisälä $(N)$ rata-rata tiap kedalaman

Frekuensi Brunt-Väisälä $(N)$ rata-rata relatif tinggi ditemukan pada permukaan hingga $5 \mathrm{~m}$ ke bawah (Gambar 4), berbanding lurus dengan profil gradien yang ditemukan pada kedalam tersebut (Gambar 3). Pengaruh angin yang lebih kuat disertai penurunan suhu permukaan laut akan meningkatkan pencampuran vertikal pada lapisan permukaan, sedangkan angin yang lebih lemah disertai pemanasan permukaan laut mengakibatkan proses pencampuran pada lapisan permukaan yang tidak sempurna sehingga meningkatkan gradien dan stabilitas permukaan perairan (Santos-Garcia et al., 2014; Roseli et al., 2015). Roseli et al. (2015), memaparkan bahwa kecepatan angin $0-3 \mathrm{~m} / \mathrm{s}$, belum mampu mencampuri lapisan permukaan perairan dengan sempurna. Hal ini membuktikan hasil penelitian, dimana hasil perkiraan model ECMWF $\left(8.25^{\circ} \mathrm{LS} ; 115.625^{\circ} \mathrm{BT}\right)$ diperoleh kecepatan angin rata-rata 14 hari pengambilan data CTD (20 Februari - 5 Maret 2019) yaitu 1,836 m/s (Tabel 2), serta pada bulan Februari dan Maret 2019 diperoleh kecepatan angin rata-rata relatif kecil dibandingkan dengan bulan lainnya yaitu kisaran 2,2 - 2,7 m/s (Gambar 5).

Tabel 2. Kecepatan angin tiap hari pengambilan data

\begin{tabular}{cc}
\hline $\begin{array}{c}\text { Tanggal } \\
\text { Pengambilan CTD }\end{array}$ & $\begin{array}{c}\text { Kecepatan Angin } \\
(\mathbf{m} / \mathbf{s})\end{array}$ \\
\hline 20 Februari 2019 & 0,603 \\
21 Februari 2019 & 0,718 \\
22 Februari 2019 & 0,74 \\
23 Februari 2019 & 2,218 \\
24 Februari 2019 & 2,334 \\
25 Februari 2019 & 2,692 \\
26 Februari 2019 & 2,865 \\
27 Februari 2019 & 2,097 \\
28 Februari 2019 & 1,577 \\
1 Maret 2019 & 2,167
\end{tabular}




\begin{tabular}{cc} 
2 Maret 2019 & 1,347 \\
3 Maret 2019 & 2,174 \\
4 Maret 2019 & 1,715 \\
5 Maret 2019 & 2,452 \\
\hline Rata-rata & $\mathbf{1 , 8 3 6}$ \\
\hline
\end{tabular}

Sumber: ECMWF

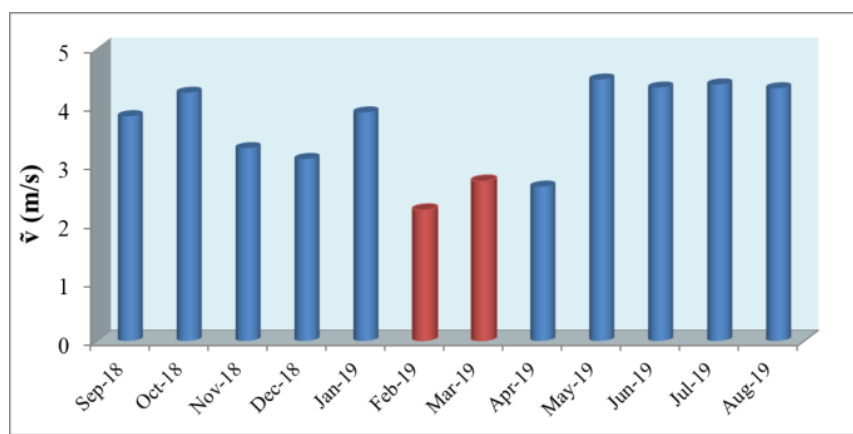

Gambar 5. Kecepatan angin rata-rata per-bulan (September 2018 - Agustus 2019) di Perairan Amed dan Tulamben; diagram tabung merah merupakan kecepatan angin rata-rata pada bulan Februari dan Maret 2019 (ECMWF)

\subsection{Laju Perubahan Konsentrasi Salinitas dan TDS}

Laju perubahan konsentrasi salinitas berkisar antara 2,94 x $10^{-5}-15,82 \times 10^{-5} \mathrm{PSS} / \mathrm{s}$ dan laju perubahan konsentrasi TDS

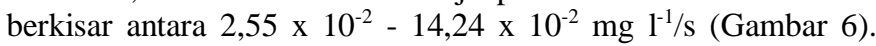
Laju perubahan salintas dan TDS di permukaan perairan relatif tinggi, kemudian menurun di kedalaman 5 - $10 \mathrm{~m}$, laju perubahan perlahan meningkat namun masih tergolong relatif rendah di kedalaman 15 - $30 \mathrm{~m}$. Laju perubahan mengalami peningkatan signifikan pada kedalaman $35 \mathrm{~m}$ hingga mencapai puncak maksimum pada kedalaman $70 \mathrm{~m}$, kembali mengalami penurunan secara signifikan hingga kedalaman $95 \mathrm{~m}$. Hingga sekarang penelitian yang membahas laju perubahan konsentrasi salinitas dan TDS secara vertikal di perairan masih sangat minim dilakukan, namun indikasi awal menyebabkan hal tersebut adalah arus perairan. Arus merupakan gerakan massa air yang dapat digambarkan melalui kecepatan dan arah geraknya, mengakibatkan perpindahan massa air dalam kolom perairan yang pada akhirnya mengendalikan perubahan fisik perairan (Hutabarat and Evans, 1985; Purba and Pranomo, 2015).

Laju perubahan relatif tinggi pada permukaan perairan disebabkan oleh arus permukaan yang digerakkan oleh faktor eksternal yaitu angin (Stewart, 2009). Gaya gesek antara angin dengan lapisan permukaan perairan akan menghasilkan daya gerak terhadap lapisan tersebut, sehingga tercipta aliran massa air permukaan (Theoyana et al., 2015). Penelitian yang dilakukan oleh Atmadipoera and Mubaraq (2016), menjelaskan bahwa pengaruh angin (wind stress) akan meningkatkan fluktuasi kecepatan arus permukaan Laut Sulawesi yang mencapai $0,5 \mathrm{~ms}^{-}$ ${ }^{1}$. Gesekan antara lapisan permukaan dengan lapisan yang berada dibawahnya menyebabkan kecepatan arus semakin berkurang seiring dengan bertambahnya kedalaman (laju perubahan relatif rendah pada kedalaman $5-30 \mathrm{~m}$ ), hal ini berkaitan dengan teori Ekman dan gaya Coriolis (Aziz, 2006).

Laju perubahan salinitas dan TDS mencapai nilai maksimum pada pada lapisan haloklin. Sebagian besar transpor massa air terjadi pada lapisan tersebut, sedangkan hubungan korelasi transpor massa air dengan angin munson hanya sebesar 0,179
(Mahie dan Megawati, 2015). Tinggi laju perubahan salinitas dan TDS pada lapisan tersebut disebabkan oleh aliran arus dalam yang melewati perairan Amed dan Tulamben. Atmadipoera dan Mubaraq (2016), menjelaskan bahwa, kecepatan arus maksimum ditemukan pada kolom perairan disebabkan oleh Indonesian Throughflow (ITF) yang melewati Laut Sulawesi dan relatif menurun saat mendekati dasar. Arus harmonik atau sering disebut arus pasang-surut juga dapat mendistorsi kolom perairan yang menyebabkan besarnya laju perubahan salinitas dan TDS (Theoyana et al., 2015). Setelah laju perubahan salinitas dan TDS maksimum yang terjadi pada kedalaman $70 \mathrm{~m}$, laju perubahan cenderung menurun hingga kedalaman $95 \mathrm{~m}$. Laju perubahan yang menurun disebabkan oleh gesekan dengan dasar perairan yang kasar akan memperlambat arus pada lapisan bawah perairan (Pineda, 1999). Hal ini juga dapat dijelaskan oleh penelitian sebelumnya yang dilakukan oleh Gordon et al. (2010) dengan membandingkan kecepatan arus harmonik (pasang-surut) maksimum pada kolom perairan Selat Lombok berkisar antara 2,23 - 2,4 $\mathrm{m} \mathrm{s}^{-1}$, dibandingkan dengan lapisan dekat dasar perairan relatif lebih rendah berkisar antara 1,82-1,98 $\mathrm{m} \mathrm{s}^{-1}$.

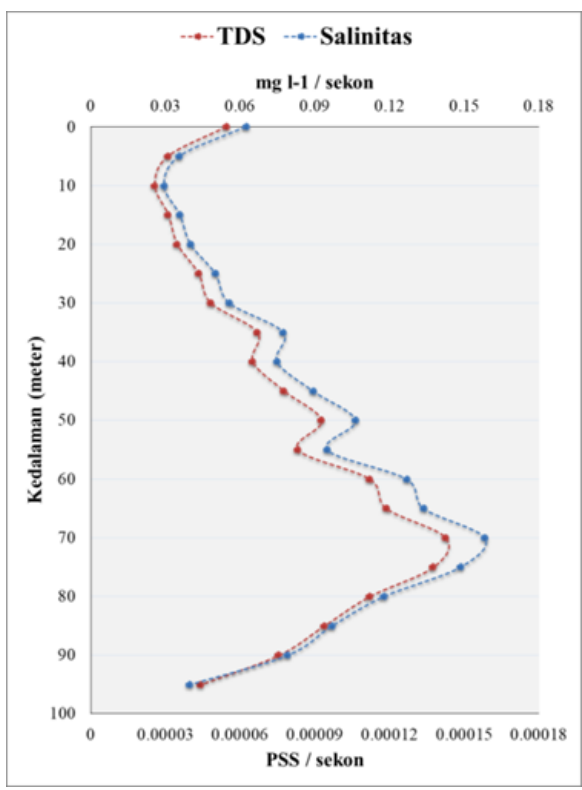

Gambar 6. Profil laju perubahan konsentrasi salinitas dan TDS tiap kedalaman

\subsection{Profil Vertikal Konsentrasi Salinitas dan TDS berdasarkan Kondisi Pasang-Surut}

Profil vertikal salinitas dan TDS dari kondisi pasang-surut berbeda di stasiun utama Batu Niti dapat dilihat pada (Gambar 8). Kondisi 5 jam sebelum pasang tertinggi, stratifikasi profil vertikal perairan sangat terlihat jelas, dimana lapisan homogen ditemukan hingga kedalaman $20 \mathrm{~m}$ sedangkan lapisan haloklin ditemukan dari kedalaman 20 - 65 m. Kondisi 4 jam sebelum pasang tertinggi, lapisan haloklin ditemukan lebih tebal dengan kisaran kedalaman $20-80 \mathrm{~m}$. Kondisi 2 jam sebelum pasang tertinggi, lapisan homogen menekan lapisan haloklin yang ada di bawahnya sehingga lapisan homogen semakin tebal hingga kedalaman $25 \mathrm{~m}$. Kondisi 1 jam sebelum pasang tertinggi, stratifikasi profil vertikal perairan kurang terlihat secara jelas, pola yang terbentuk hampir sama dari permukaan hingga batas kedalaman akhir pengukuran $(95 \mathrm{~m})$. Hal yang hampir sama ditemukan pada kondisi pasang tertinggi, namun indikasi terbentuknya lapisan haloklin di kedua kondisi tersebut terjadi dari kedalaman $20 \mathrm{~m}$ (gradien salinitas lebih besar dibandingkan kedalaman diatasnya). Stratifikasi profil vertikal perairan kembali terlihat jelas pada kondisi 1 jam setelah pasang tertinggi, dimana 
lapisan homogen ditemukan hingga kedalaman 20 m sedangkan lapisan haloklin ditemukan dari kedalaman 20 - 75 m, gradien salinitas relatif tinggi juga ditemukan di permukaan $(0-5 \mathrm{~m})$ akibat pengaruh angin yang lemah pada kondisi tersebut (SantosGarcia et al., 2014). Kondisi 2 jam setelah pasang tertinggi, lapisan homogen lebih tebal dibandingkan kondisi sebelumnya yaitu hingga kedalaman $30 \mathrm{~m}$, sedangkan lapisan haloklin ditemukan dari kedalaman 30 - $85 \mathrm{~m}$. Angin mempengaruhi proses mixing pada lapisan homogen, semakin besar energi pembangkitnya maka lapisan homogen semakin tebal (Sidabutar et al., 2014; Harsono, 2012 in Saraswati, 2017). Cavalcane et al. (2010), menjelaskan bahwa saat kondisi air surut tingkat stratifikasi perairan akan semakin tinggi atau jelas terlihat, sedangkan saat kondisi air pasang hingga pasang tertinggi tingkat stratifikasi perairan semakin melemah.

Secara fisis, profil vertikal salinitas dan TDS berdasarkan kondisi pasang-surut yang berbeda-beda (Gambar 8), mengalami peningkatan konsentrasi seiring bertambahnya kedalaman. Salinitas berbanding lurus dengan densitas (massa jenis), dimana massa air berdensitas tinggi akan berada di bawah massa air berdensitas rendah, begitu juga apabila terjadi ketidakstabilan, gaya gravitasi akan menekan ke bawah massa air yang lebih berat (densitas tinggi) dan gaya apung akan membawa massa air lebih ringan (densitas rendah) terangkat ke atas (Pickard and Emery, 1990). Salinitas sangat mempengaruhi konsentrasi oksigen terlarut (DO) di perairan, semakin tinggi tingkat salinitas mengakibatkan semakin rendah konsentrasi DO (Miller et al.,
1988). Akumulasi bahan organik dari sisa pakan dan proses ekskresi organisme perairan atau proses regenerasi bahan organik (meningkatnya konsentrasi TDS), serta berkurangnya cahaya yang masuk ke kolom perairan menyebabkan penurunan konsentrasi oksigen terlarut terjadi pada lapisan haloklin (Sigman, 2010). Penelitian yang dilakukan oleh Hamzah dan Trenggono (2014), menghasilkan bahwa perairan pada bagian barat Selat Lombok yang mendapat pengaruh langsung dari ITF (dekat kawasan Amed dan Tulamben) memiliki nilai DO yang relatif lebih tinggi dibandingkan dengan bagian timur Selat Lombok (dekat kawasan Gili Matra) akibat aktivitas pertanian, rumah tangga, dan pariwisata yang mampu meningkatkan bahan organik.

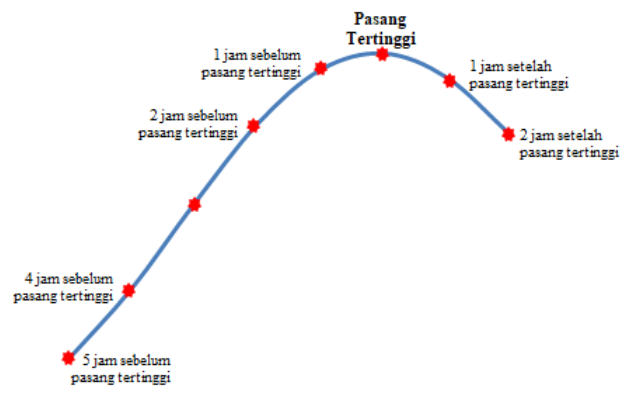

Gambar 7. Kondisi pasang-surut yang dikelompokkan berdasarkan akumulasi pengambilan data CTD

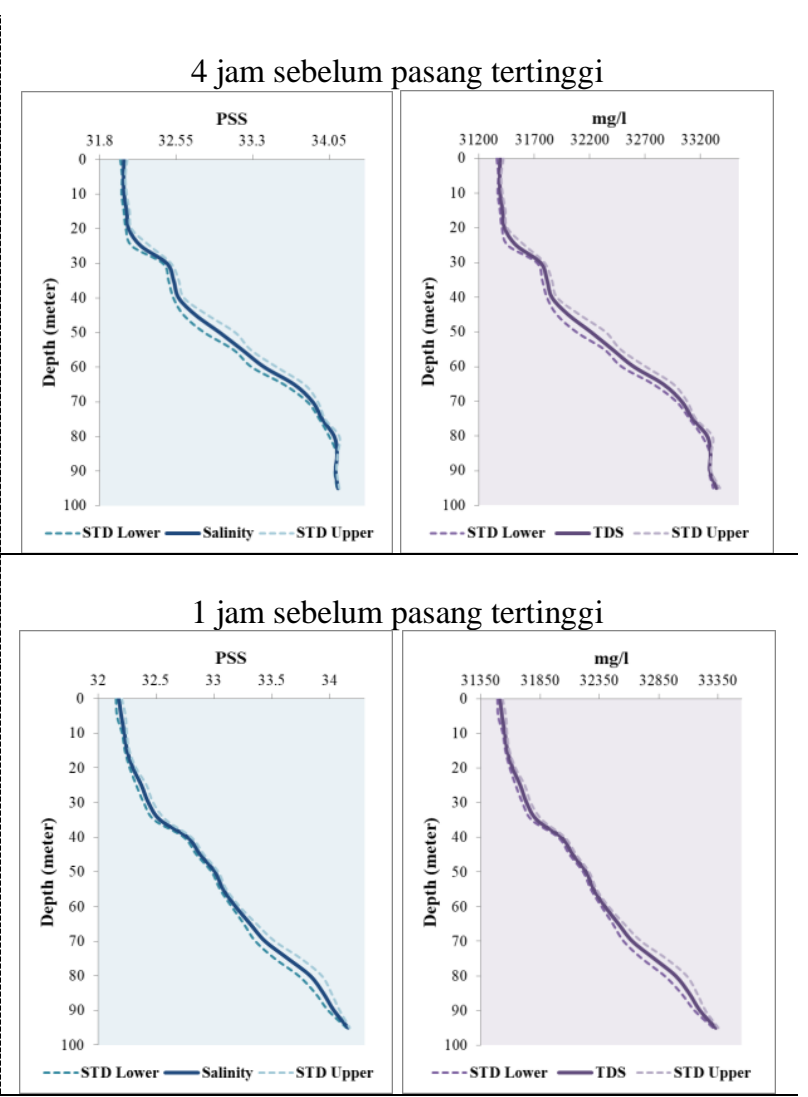




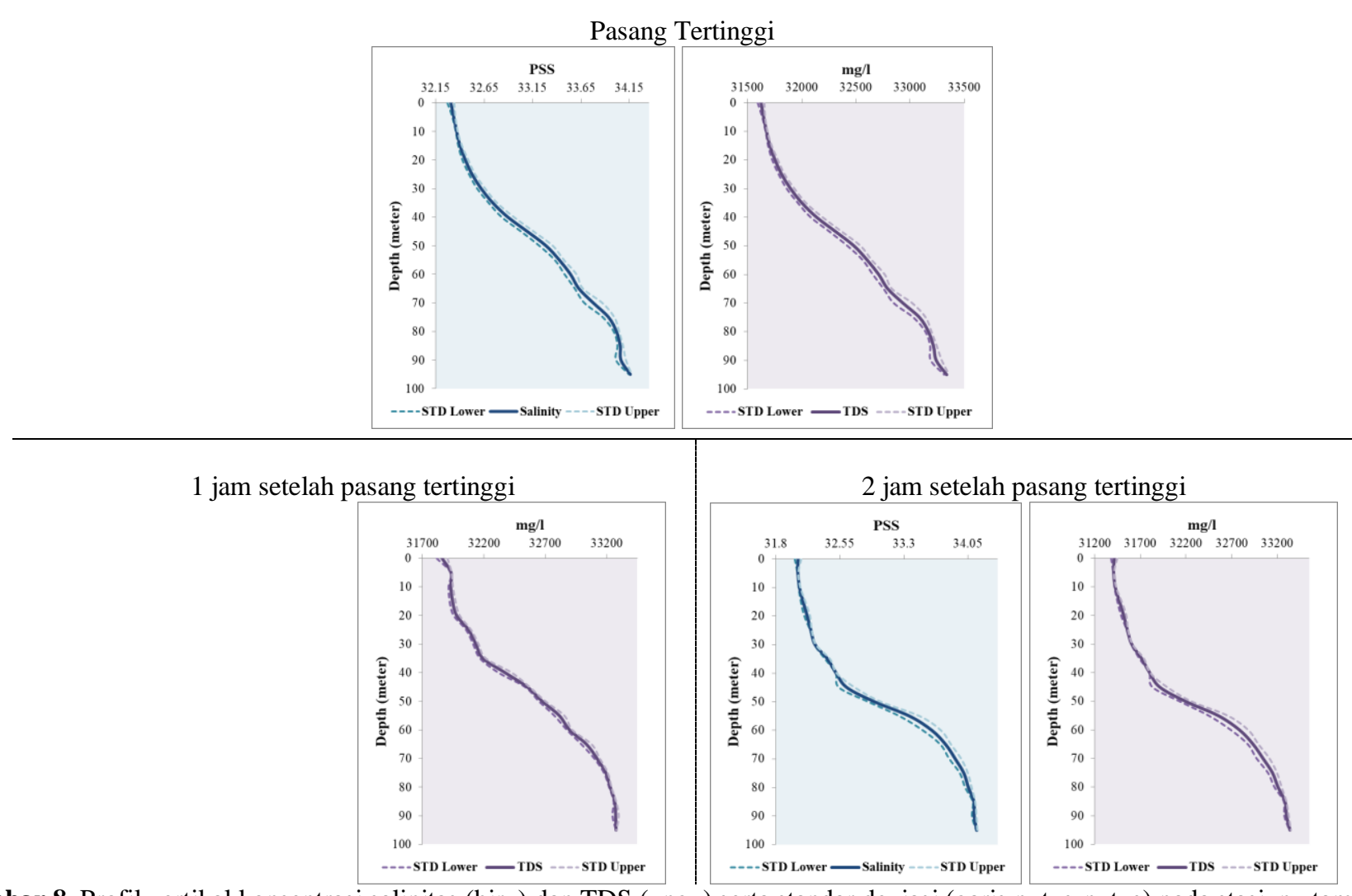

Gambar 8. Profil vertikal konsentrasi salinitas (biru) dan TDS (ungu) serta standar deviasi (garis putus-putus) pada stasiun utama Batu Niti berdasarkan kondisi pasang-surut

Deviasi atau variabilitas data dalam pengukuran temporal mengindikasikan adanya perubahan dinamis karakteristik massa air pada suatu lapisan perairan (Nagasawa et al., 2002; MacKinnon dan Winters, 2005). Secara keseluruhan hasil kondisi pasang-surut yang diperoleh (Gambar 8), nilai standar deviasi (ditandai dengan garis putus-putus) relatif lebih tinggi pada lapisan haloklin. Deviasi nilai suatu variabel yang diidendifikasikan sebagai gambaran perubahan variabel tersebut, sehingga hasil analisis ini berkaitan dengan hasil analisis laju perubahan pada (Gambar 6) yang ditemukan lebih tinggi juga pada lapisan haloklin. Pasang-surut internal (internal tides) memiliki pengaruh yang kuat dalam mengendalikan vertical mixing serta variabilitas temperatur dan salinitas pada lapisan termohalin, semakin tinggi kecepatan arus pasang-surut internal maka nilai deviasi yang dihasilkan juga semakin tinggi (Pineda, 1999; Cacchione et al., 2002; Melet et al., 2013).

Kondisi sebelum pasang tertinggi memiliki selisih nilai standar deviasi maksimum dengan minimum tertinggi yaitu 0,1434 PSS dan $127,7058 \mathrm{mg} \mathrm{l}^{-1}$, dibandingkan dengan dua kondisi pasang-surut lainnya (Tabel 3). Selisih nilai standar deviasi pada kondisi setelah pasang tertinggi yaitu 0,0818 PSS dan $76,749 \mathrm{mg} \mathrm{l}^{-1}$, memiliki nilai yang hampir sama dengan kondisi pasang tertinggi yaitu $0,0857 \mathrm{PSS}$ dan $75,711 \mathrm{mg} \mathrm{l}^{-1}$. Hal ini terjadi akibat selisih nilai standar deviasi paling rendah dihasilkan pada kondisi 1 jam setelah pasang tertinggi $(0,0583$ PSS dan 51,8271 $\mathrm{mg} \mathrm{l}^{-1}$ ). Pada kondisi pasang tertinggi maupun pasang terendah terjadi aliran arus berbalik (dari pasang ke surut atau sebaliknya) yang dinamakan slack water, sehingga kecepatan arus pasang-surut minimum hingga mendekati nol (Triatmodjo, 2006 in Nurjaya and Surbakti, 2009). Kondisi setelah pasang tertinggi (menuju surut) memiliki selisih nilai standar deviasi yang lebih rendah dibandingkan kondisi sebelum pasang tertinggi (menuju pasang), yang mengindikasikan kecepatan arus pasang-surut lebih rendah terjadi pada kondisi menuju surut, hal yang sama ditemukan pada penelitian Budiman et al. (2014) di Teluk Mayalibit-Papua dan Kusmanto et al. (2016) di perairan pesisir Probolinggo. Menurut Murray and Arief (1988), Selat Lombok memiliki tipe pasang-surut semidiurnal (periode 12,4 jam), dimana jarak antara pasang tertinggi dan terendah $6-7$ jam, sehingga kondisi pasang-surut yang lebih dekat dengan pasang tertinggi memiliki nilai standar deviasi yang lebih rendah (dapat dilihat pada kondisi 5 jam sebelum pasang tertinggi, 1 jam sebelum dan setelah pasang tertinggi), dibandingkan dengan kondisi 2 jam sebelum dan setelah pasang tertinggi menghasilkan nilai standar deviasi yang lebih tinggi.

Tabel 3. Standar deviasi salinitas dan TDS pada kondisi pasang-surut berbeda

\begin{tabular}{llcccccc}
\hline & \multicolumn{3}{c}{ Standar Deviasi Salinitas (PSS) } & \multicolumn{3}{c}{ Standar Deviasi TDS (mg/l) } \\
\cline { 2 - 7 } & Maksimum & Minimum & Selisih & Maksimum & Minimum & Selisih \\
\hline Pasang Tertinggi & $\mathbf{0 , 0 9 1 3}$ & $\mathbf{0 , 0 0 9 5}$ & $\mathbf{0 , 0 8 1 8}$ & $\mathbf{8 4 , 0 4 3}$ & $\mathbf{8 , 2 9 4}$ & $\mathbf{7 6 , 7 4 9}$ \\
\hline $\begin{array}{l}\text { Sebelum Pasang } \\
\text { Tertinggi }\end{array}$ & $\mathbf{0 , 1 5 0 9}$ & $\mathbf{0 , 0 0 7 5}$ & $\mathbf{0 , 1 4 3 4}$ & $\mathbf{1 3 5 , 8 4 1 4}$ & $\mathbf{8 , 1 3 5 6}$ & $\mathbf{1 2 7 , 7 0 5 8}$ \\
$\begin{array}{l}\text { 1 jam sebelum } \\
\text { Pasang Tertinggi }\end{array}$ & 0,1133 & 0,014 & 0,0993 & 102,1651 & 17,0989 & 85,0662 \\
2 jam sebelum & 0,2301 & 0,0059 & 0,2242 & 211,9585 & 5,1116 & 206,8469 \\
\hline
\end{tabular}


Pasang Tertinggi

\begin{tabular}{lcccccc}
$\begin{array}{l}\text { 4 jam sebelum } \\
\text { Pasang Tertinggi }\end{array}$ & 0,1516 & 0,0058 & 0,1458 & 132,2731 & 5,603 & 126,6701 \\
$\begin{array}{l}\text { 5 jam sebelum } \\
\text { Pasang Tertinggi }\end{array}$ & 0,1087 & 0,0044 & 0,1043 & 96,969 & 4,729 & 92,24 \\
\hline $\begin{array}{l}\text { Setelah Pasang } \\
\text { Tertinggi }\end{array}$ & $\mathbf{0 , 0 8 9 7}$ & $\mathbf{0 , 0 0 4}$ & $\mathbf{0 , 0 8 5 7}$ & $\mathbf{7 8 , 5 4 4 1}$ & $\mathbf{2 , 8 3 3 1}$ & $\mathbf{7 5 , 7 1 1}$ \\
$\begin{array}{l}\text { 1 jam setelah } \\
\text { Pasang Tertinggi }\end{array}$ & 0,0617 & 0,0034 & 0,0583 & 53,6145 & 1,7875 & 51,8271 \\
$\begin{array}{l}\text { 2 jam setelah } \\
\text { Pasang Tertinggi }\end{array}$ & 0,1177 & 0,0046 & 0,1131 & 103,4737 & 3,8788 & 99,5949 \\
\hline
\end{tabular}

Perbandingan profil vertikal dan nilai standar deviasi antara kedua stasiun penelitian (Gambar 9) menarik untuk dibahas. Pada stasiun kontrol Emerald pengukuran dilakukan selama tiga hari yaitu 22, 24, dan 26 Februari sehingga hanya mendapatkan data hasil pengukuran yang lebih sedikit untuk mewakili kondisi pasang-surut perairan tersebut. Teknik analisis deskriptif dilakukan dengan membandingkan kondisi pasang-surut yang sama antara kedua stasiun. Pada kondisi pasang tertinggi, membentuk profil vertikal yang berbeda antara kedua stasiun (Gambar 9 (a)), dimana stratifikasi vertikal perairan lebih jelas terlihat di Emerald, lapisan haloklin ditemukan dari 30 mdisertai nilai standar deviasi yang sangat tinggi pada lapisan tersebut (rata-rata nilai standar deviasi salinitas 0,2093 PSS dan TDS 191,7434 $\mathrm{mg} \mathrm{l}^{-1}$ ). Hasil perbandingan yang hampir sama ditemukan pada kondisi 1 jam sebelum pasang teringgi (Gambar 9 (b)), statifikasi perairan terlihat lebih jelas di perairan Emerald, lapisan haloklin ditemukan dari kedalaman $50 \mathrm{~m}$ (lebih dalam daripada kondisi pasang tertinggi) dengan rata-rata nilai standar deviasi salinitas 0,2384 PSS dan TDS 212,7001 $\mathrm{mg} \mathrm{l}^{-1}$. Profil vertikal perairan yang hampir seragam antara kedua stasiun ditemukan pada kondisi 1 jam setelah pasang tertinggi (Gambar 9 (c)), namun selisih konsentrasi salinitas dan TDS yang relatif tinggi terjadi (selisih $\geq 0,2 \mathrm{PSS}$; $\geq 200 \mathrm{mg} \mathrm{l}^{-1}$ ) dari permukaan hingga kedalaman $50 \mathrm{~m}$.

Tingginya nilai standar deviasi di perairan Emerald (kondisi pasang tertinggi dan 1 jam sebelum pasang tertinggi), mengindikasikan adanya pengaruh dari arus pasang-surut internal yang lebih kuat pada perairan tersebut. Arus pasangsurut internal terbentuk dari proses disipasi energi pasang-surut barotropik ke baroklinik (internal) sebagai hasil interaksi dengan hambatan topografi perairan, yang selanjutnya akan membangkitkan proses turbulensi kolom perairan atau tidal mixing (Jayne et al., 2004 in St. Laurent et al., 2012; Hall et al., 2011; Chinn et al., 2012). Dinamika komponen fisik internal memainkan peran penting dalam suplai kebutuhan nutrien kolom perairan, yang selanjutnya akan menentukan tingkat biodiversitas suatu perairan (Bertrand et al., 2008; Lee et al., 2009). Biota laut memiliki tingkat kerentanan dan kemampuan untuk berpindah dari lingkungan perairan yang tidak menguntungkan tanpa terkecuali komponen fisik perairan, dimana kecepatan arus yang tinggi tidak baik bagi perkembangan dan kemampuan hidup larva ikan (Rojas and Landaeta, 2014), serta mikroalga sebagai pemegang peranan penting dalam produktivitas perairan memiliki tingkat kerentanan yang lebih tinggi terhadap turbulensi yang disebabkan oleh angin (Queiroz et al., 2004). Penjelasan tersebut tidak cukup untuk membuktikan keterkaitan komponen fisik dan biologis pada perairan tersebut, penelitian mengenai proses hidrodinamika lokal lebih kompleks (Falter $e t$ al., 2013), serta pengamatan biodiversitas perairan secara in situ perlu dilakukan.
Analisis ini menjadi menarik untuk dibahas lebih lanjut apabila dikaitkan dengan objek penelitian UNSEEN yaitu mesophotic coral ecos ystem (MCE). MCE terdiri dari komunitas karang rendah cahaya yang ditemukan lebih dalam dari shallow water reefs (SWR) yaitu sekitar kedalaman 30 $150 \mathrm{~m}$ (Hinderstein et al., 2010), memiliki tingkat biodiversitas tinggi dan sebagai habitat bagi spesies penting seperti Molamola (Papastamatiou et al., 2015; Rosa et al., 2016). MCE berpotensi menyediakan perlindungan dan sumber nutrien bagi ketahanan SWR, namun studi mengenai MCE (di bawah kedalaman $40 \mathrm{~m}$ ) serta hubungannya dengan faktor oseanografi belum banyak dikaji (Menza et al., 2007; Loya et al., 2016). Dinamika internal perairan yang diakibatkan oleh arus dan gelombang menjadi faktor penting dalam mengatur suplai nutrien dan ekologi MCE (Bongaerts et al., 2011; Bridge et al., 2011).

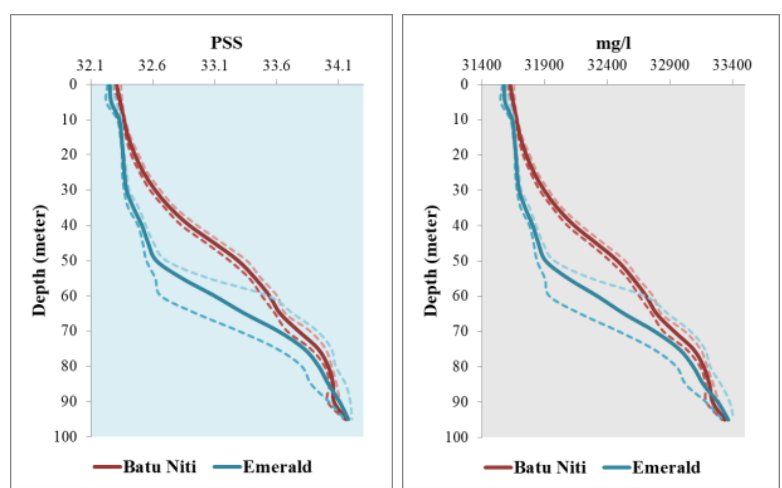

(a)

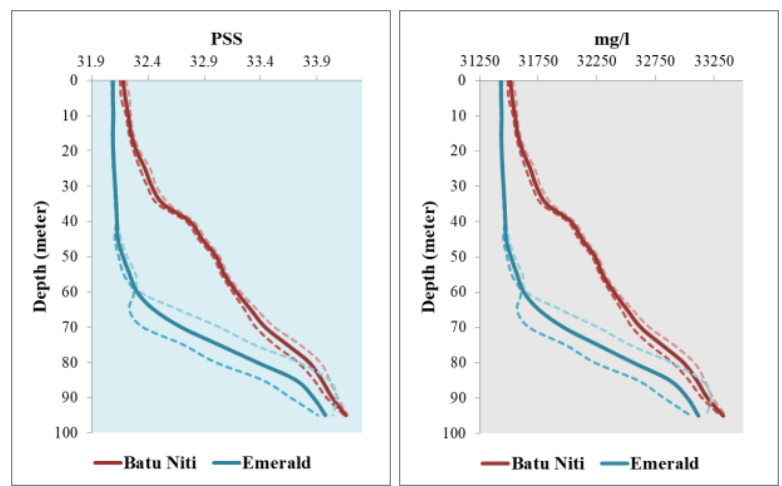

(b) 

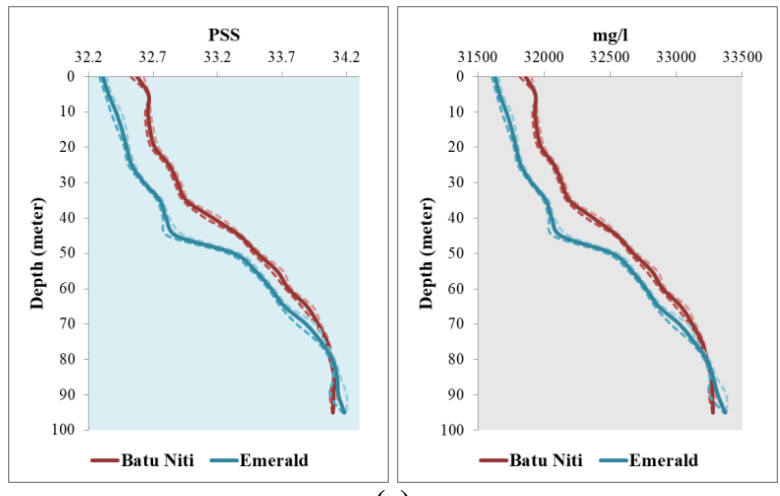

(c)

Gambar 9. Perbandingan profil vertikal dan standar deviasi salinitas dan TDS pada stasiun utama (Batu Niti) dan stasiun kontrol (Emerald); (a) kondisi pasang tertinggi; (b) kondisi 1 jam sebelum pasang tertinggi; (c) kondisi 1 jam setelah pasang tertinggi

\section{Kesimpulan}

Konsentrasi salinitas yang diperoleh melalui sensor elektroda CTD dan konsentrasi TDS yang dihasilkan dari sistem persamaan rasio jenis air, memiliki hubungan korelasi yang sangat kuat karena kedua parameter diukur melalui karakteristik konduktivitas perairan. Lapisan haloklin $(\geq 0,01$ $\mathrm{PSS} / \mathrm{m}$ ) ditemukan dari kedalaman $20 \mathrm{~m}$, sedangkan lapisan homogen ditemukan dekat permukaan (5 - 19 m). Tingkat stabilitas perairan dapat diketahui melalui frekuensi BruntVäisälä $(N)$. Besarnya stabilitas perairan berbanding lurus dengan gradien perairan, dimana lapisan haloklin memiliki tingkat stabilitas perairan lebih tinggi dibandingkan lapisan homogen. Pengaruh angin yang lemah menyebabkan nilai $N$ juga ditemukan relatif tinggi pada permukaan perairan hingga $5 \mathrm{~m}$ ke bawah. Laju perubahan konsentrasi salinitas dan TDS tertinggi terjadi pada lapisan haloklin (kecepatan maksimum pada kedalaman $70 \mathrm{~m}$ ). Pengaruh arus pasang-surut internal yang tinggi akan menciptakan deviasi konsentrasi salinitas dan TDS. Kondisi sebelum pasang tertinggi stasiun Batu Niti diperoleh selisih nilai standar deviasi tertinggi. Pengukuran di stasiun Emerald menghasilkan nilai standar deviasi jauh lebih tinggi dibandingkan di stasiun Batu Niti, yang dapat menjadi faktor pembeda biodiversitas dan ekologi kedua perairan.

\section{Ucapan Terimakasih}

Penelitian ini didanai oleh Underwater Scientific Exploration and Education (UNSEEN) .

\section{Daftar Pustaka}

Aiki H, Matthews JP, Lamb KG. 2011. Modeling and energetics of tidally generated wave trains in the Lombok Strait: Impact of the Indonesian Throughflow. J. Geophys Res Vol. 116 : 10-29

Allen GR.. 2007. Conservation hotspots of biodiversity and endemism for Indo-Pacifc coral reef fshes. Aquatic Conservation (Marine and Freshwater Ecosystems) Journal Vol. 18 : 541-556

Andrianto T. 2005. Pedoman Praktis Budidaya Ikan Kerapu Macan. Yogyakarta : Absolut. In : Amri K, Muchlizar, Ma'min A. 2018. Monthly variation of salinity, $\mathrm{pH}$, and disolved oxygen in Bengkalis Estuarine. Majalah Ilmiah Globë Vol. 20 (2) : 57-66

Atmadipoera AS, Molcard R, Madec G, Sprintall J, Wijffels S, Supangat A. 2009. Inflow between Asmore and North Coast of Australia and its Impact on Timor Passage Throughflow. Manado : WOC Manado Indonesia

Atmadipoera AS, Mubaraq GL. 2016. Struktur dan variabilitas Arlindo di Laut Sulawesi. Jurnal Kelautan Nasional Vol. 11 (3) : 159-174

Aziz MF. 2006. Gerak air di laut. J. Oseana Vol. 31 (4) : 9-21
Bertrand A, Gerlotto F, Bertrand S, Gutiérrez M, Alza L, Chipollini A, Díaz E, Espinoza P, Ledesma L, Quesquén R, Peraltilla S, Chavez F. 2008. Schooling behaviour and environmental forcing in relation to anchoveta distribution: an analysis across multiple spatial scales. Prog. Oceanogr, $79: 264-277$

Bongaerts P, Bridge TCL, Kline DI, Muir PR, Wallace CC, Beaman RJ, Hoegh Guldberg O. 2011. Mesophotic coral ecosystems on the walls of Coral Sea atolls. Coral Reefs $30: 335 \mathrm{pp}$

Bridge TCL, Done TJ, Friedman A, Beaman RJ, Williams SB, Pizarro O, Webster JM. 2011. Variability in mesophotic coral reef communities along the Great Barrier Reef, Australia. Mar Ecol Prog Ser 428 : 6375

Budiman AS, Koropitan AF, Nurjaya IW. 2014. Pemodelan hidrodinamika arus pasang surut Teluk Mayalibit Kabupaten Raja Ampat Provinsi Papua Barat. Depik Vol. 3(2) : 146-156

Cacchione DA, Pratson LF, Ogston AS. 2002. The shaping of continental slopes by internal tides [reports]. Science Vol. 296 : 724-727

Cavalcane GH, Kjerfve B, Knoppers B, Feary DA. 2010. Coastal currents adjacent to the Caeté Estuary, Pará Region, North Brazil. Elsevier: Estuarine, Coastal and Shelf Science Vol. 88 (1) : 84-90

Chinn BS, Girton JB, Alford MH. 2012. Observations of internal waves and parametric subharmonic instability in the Philippines archipelago. J. Geophys. Res. Vol. 117 (C05019) : 12 pages

Clescerl LS. Greenberg AE, Eaton AD. 1998. Standard methods for the examnination of water and wastewater (20th ed). Maryland: United Book Press. In : Choo-in S. 2019. The relationship between the total dissolved Solids and the conductivity value of drinking water, surface water and wastewater. International Academic Research Conference ; Amsterdam, 2019. 16 pages

Corsin TS. 2007. Extended application of hot wire anemometer. Rev. Scient. Instrum. Vol. 18 : 469-471. In : Kusuma YF, Sulistiya. 2018. Pengukuran kecepatan angin di dalam dan sekitar model stasiun menggunakan Constant Temperature Anemometer. Journal of Aero Technology Vol. 1(2) : 19-27

Delcroix T, McPhaden M. 2002. Interannual sea surface salinity and temperature changes in the western Pacific warm pool during 19922000. J. Geophys. Res. Vol. 107 (C12, 8002) : 17 pages

Effendi H. 2003. Telaah Kualitas Air. Yogyakarta: Kanisius

Emery WJ, Thomson RE. 1997. Data Analysis Method in Physical Oceanography. UK : British Library Catalogue

Falter JL, Lowe RJ, Zhang Z, McCulloch M. 2013. Physical and biological controls on the carbonate chemistry of coral reef waters: effects of metabolism, wave forcing, sea level, and geomorphology. Plos One Vol. 8 (1) : 1-19

Gargett A, Garner T. 2008. Determining Thorpe scales from ship-lowered CTD density profiles. Journal of Atmospheric and Oceanic Technology Vol. 25 : 1657-1670

Gordon A, Sprintall J, van Aken HM, Susanto D, Wijffels S, Molcard R, Ffield A, Pranowo WS, Wirasantosa S. 2010. The Indonesian Throughflow during 2004- 2006 as observed by the INSTANT program. Dynamics of Atmospheres and Oceans Vol. 50 (2) : 115-128

Graff JR, Menden-Deuer S. 2016. Physical and optical properties of phytoplanktonrich layers in a coastal fjord: a step toward prediction and strategic sampling of plankton patchiness. Mar. Ecol. Prog. Ser. Vol. $544: 1-14$

Hall RA, Huthance JM, Wiliams RG. 2011. Internal tides, nonlinear internal wave trains, and mixing in the Faroe Shetland Channel. Journal of Goephysical Research Vol. 116, C03008 : 1-5

Hamzah F, Trenggono M. 2014. Oksigen terlarut di Selat Lombok. Jurnal Kelautan Nasional Vol. 9 (1) : 21-35

Harianti A, Veronica S, Setiawan S, Iskandar D. 2012. Statistika II. Edisi Pertama. Andi. Yogyakarta

Harsono G. 2012. Fenomena barrier layer 01 perairan ekuatorial Pasifik Barat. In : Saraswati VW. 2017. Stratifikasi massa air Laut Maluku [skripsi]. Bogor : Departemen Ilmu dan Teknologi Kelautan Fakultas Perikanan dan Ilmu Kelautan Institut Pertanian Bogor. 40 hal.

Harvianto L, Parenkuan M, Koropitan AF, Agustiadi T. 2015. Analisis diagram T-S berdasarkan parameter oseanografi di perairan Selat Lombok. Journal of Technology Vol. 1 (1) : 101-117. ISSN : 24608777

Hastono SP. 2006. Basic Data Analysis for Health Research. Universitas Indonesia (UI) : Fakultas Kesehatan Masyarakat

Hem JD. 1970. Study and interpretation of the chemical characteristics of natural waters $\left(2^{\text {nd }}\right.$ ed.). U.S : Geological Survey Water-Supply Paper 1473. 361 pages. In : Pradhan B, Pirasteh S. 2011. Hydro-chemical analysis of the ground water of the basaltic catchments: upper Bhatsai Region, Maharastra. The Open Hydrology Journal Vol. 5 : 51-57 
Hendrawan IG, Asai K. 2011. Numerical study of tidal upwelling over the sill in the Lombok Strait (Indonesia). Proceedings of the Twenty-first (2011) International Offshore and Polar Engineering Conference Maui ; Hawaii, USA, June 19-24, 2011. 949-956 pages. ISSN 10986189

Hinderstein LM, Marr JCA, Martinez FA, Dowgiallo MJ, Puglise KA, Pyle RL, Zawada DG, Appeldoorn R. 2010. Theme section on "mesophotic coral ecosystems: characterization, ecology, and management". Coral Reefs 29 : 247-251

Hutabarat S, Evans SM. 1985. Pengantar Oseanografi. Jakarta : UI Press

Jayne SR, St. Laurent LC, Gille ST. 2004. Connections between ocean bottom topography and Earth's climate. In : St. Laurent LM, Alford MH, Paluszkiewicz T. 2012. An introduction to the special issue on internal waves. J. Oceanography Vol. 25(2) : 15-19

Karang IWGA, Nishio F, Osawa T. 2010. Estimation of tidal energy dissipation and diapycnal diffusivity in the Indonesian Seas. International Journal of Remote Sensing and Earth Sciences Vol. 7 : 53-72

Karang IWGA, Nishio F, Mitnik L, Osawa T. 2012. Spatial-temporal distribution and characteristics of internal waves in the Lombok Strait area studied by alos-palsar images. Earth Science Research Vol. 1(2) : $11-22$

Karso. 1997. Buku Materi Pokok 3 : Telaah Materi Persamaan, Pertidaksamaan dan Program Linear (Telaah Materi Kurikulum Matematika SMU). Jakarta : Depdikbud, FKIP-UT

Kunarso SH, Ningsih NS, Baskoro M. 2011. Variabilitas suhu dan klorofila di daerah upwelling pada variasi kejadian ENSO dan IOD di perairan selatan Jawa sampai Timor. Jurnal Ilmu Kelautan Vol. 16(3) : 171180

Kusmanto E, Hasanudin M, Setyawan WB. 2016. Amplifikasi pasang surut dan dampaknya terhadap Perairan Pesisir Probolinggo. Oseanologi dan Limnologi di Indonesia Vol. 1 (3) : 69-80. ISSN: 2477-328X

Lee JY, Dong-Jin K, Il-Nam K, Taekeun R, Tongsup L, Chang-Keun K, Kyung-Ryul K. 2009. Spatial and temporal variability in the pelagic ecosystem of the East Sea (Sea of Japan): a review. J. Mar. Syst. Vol. $78: 288-300$

Loya Y, Eyal G, Treibitz T, Lesser MP, Appeldoorn R. 2016. Theme section on mesophotic coral ecosystems: advances in knowledge and future perspectives. Coral Reefs $35: 1-9$

Lukas R, Lindstrom E. 1991. The mixed layer of the western equatorial Pacific Ocean. J. Geophys. Res. Vol. 96 : 3343-3358

MacKinnon JA, Winters KB. 2005. Subtropical catastrophe: significant loss of low-mode tidal energy at $28.9^{\circ}$. Geophysical Research Letters Vol. 32 (L15605) : 5 pages

Mahie AG, Megawati. 2015. Pemodelan numerik princeton ocean model (POM) transport volume Arus Lintas Indonesia (Arlindo) hubungannya dengan ENSO dan monsun. Jurnal Matematika, Statistika, dan Komputasi (JMSK) Vol. 11 (2) : 159-168. ISBN: 18581382.

Marwan AH, Widyorini N, Nitisupardjo M. 2015. Hubungan total bakteri dengan kandungan bahan organik total di muara Sungai Babon, Semarang. Diponegoro Journal Of Maquares Vol. 4 (3) : 170-179.

Matthews JP, Aiki H, Masuda S, Awaji T, Ishikawa Y. 2011. Monsoon regulation of Lombok Strait internal waves. Journal of Geophysical Research Vol. 116 : 1-14

Melet A, Hallberg R, Legg S, Polzin K. 2013. Sensitivity of the ocean state to the vertical distribution of internal-tide-driven mixing. Journal of Physical Oceanography Vol. 43 : 602-615

Menza C, Kendall M, Rogers C, Miller J. 2007. A deep reef in deep trouble. Cont Shelf Res $27: 2224-2230$

Millero FJ. 2013. Chemical Oceanography $\left(4^{\text {th }} e d\right)$. U.S. : CRC Press, Taylor \& Francis Group. 547 pp

Miller RL, Bradford WL, Peters NE. 1988. Specific Conductance: Theoretical Considerations and Application to Analytical Quality Control. USA : U.S. Geological Survey Water-Supply Paper

Mitnik LM. 2006. Dynamic phenomena in the Lombok Strait and surrounding waters: imprints on ERS and Envisat SAR images. Journal of Earth Observations and Remote Sensing. Vol. 6 : 83-92

Murray SP, Arief D. 1988. Throughflow into the Indian Ocean through the Lombok Strait, January 1985 - January 1986. Nature Journal Vol. 333 : 444-447

Mustika PL, Ratha IMJ, Purwanto S. 2012. Kajian Cepat Kondisi Kelautan Provinsi Bali 2011. Ed ke-2. Denpasar : RAP Bulletin of Biological Assessment 64. 142 hal

Nagasawa MT, Hibiya Y, Niwa M, Watanabe Y, Isoda, Takagi S, Kamei Y. 2002. Distribution of fine-scale shear in the deep waters of the North Pacific obtained using expendable current profilers. J. Geophys. Res. Vol. 107 (3221) : 7 pages
Ningsih NS, Rahmayani R, Hadi S, Brojonegoro IS. 2008. Internal waves dynamics in the Lombok Strait studied by a numerical model. International Journal of Remote Sensing and Earth Sciences Vol. 5 : $17-33$

Nurhayati. 2006. Distribusi vertikal suhu, salinitas, dan arus perairan Morotai, Maluku Utara. In : Valdi MH, Taofiqurohman A, Riyantini I. 2012. Analisis massa air di perairan Maluku Utara. Jurnal Perikanan dan Kelautan Vol. 3 (1) : 1-9

Page CH, Vigoureux P. 1975. The International Bureau of Weights and Measures 1875-1975: NBS Special Publication 420. Washington, D.C. : National Bureau of Standards. 238-244 pages

Papastamatiou YP, Meyer CG, Kosaki RK, Wallsgrove NJ, Popp BN. 2015. Movements and foraging of predators associated with mesophotic coral reefs and their potential for linking ecological habitats. Mar Ecol Prog Ser 521 : 155-170

Park YH, Fuda JL, Durand I, Garabato ACN. 2008. Internal tides and vertical mixing over the Kerguelen Plateau. Deep-Sea Res. Pt. II Vol. $55: 582-593$

Patty SI. 2013. Distribusi suhu, salinitas dan oksigen terlarut di perairan Kema, Sulawesi Utara. Jurnal Ilmiah Planax Vol. 1 : 1-5

Pickard GL, Emery WJ. 1990. Descriptive Physical Oceanography: An Introduction. $5^{\text {th }}$ enlarged ed. Oxford : Pergamon Press

Pineda J. 1999. Circulation and larval distribution in internal tidal bore warm fronts. Limnol. Oceanogr. Vol. 44 (6) : 1400-1414

Pond S, Pickard GL. 1983. Introductory Dynamical Oceanography. $2^{\text {nd }}$ ed. Oxford : Pergamon Press. 329 pages. In : Suteja Y, Purba M, Atmadipoera AS. 2015. Percampuran turbulen di Selat Ombai. Jurnal Ilmu dan Teknologi Kelautan Tropis Vol. 7 (1) : 71-82

Purba NP, Pranowo WS. 2015. Dinamika Oseanografi, Deskripsi Karakteristik Massa Air dan Sirkulasi Air Laut. Bandung : UNPAD Press. 276 hlm

Purba M, Utami IN. 2006. Karakteristik dan pergerakan massa air di Selat Lombok bulan januari 2004 dan juni 2005. Jurnal Ilmu-ilmu Perairan dan Perikanan Indonesia Vol. 13 (2) : 143-153

Queiroz RL, Brandini FP, Pellizzari FM. 2004. Dynamics of microalgal communities in the water-column/sediment interface of the inner shelf off Parana State, Southern Brazil. Brazilian Journal of Oceanography Vol. 52 (3/4) : 183-194. ISSN: 1982-436x

Rinawati, Hidayat D, Suprianto R, Dewi PS. 2016. Penentuan kandungan zat padat (total dissolve Solids dan total suspended Solids) di perairan Teluk Lampung. Analit: Analytical and Environmental Chemistry Vol. 1 (1) : 36-45

Rojas PM, Landaeta MF. 2014. Fish larvae retention linked to abrupt bathymetry at Mejillones Bay (northern Chile) during coastal upwelling events. J. Aquat. Res. Vol. 42 (5) : 989-1008. E-ISSN: 0718-560x

Rosa MR, Alves AC, Medeiros DV, Coni EOC, Ferreira CM, Ferreira BP, Rosa R, Souza R, Amado-Filho GH, de Moura RL, Thompson FL, Sumida PYG, Francini-Filho RB. 2016. Mesophotic reef fish assemblages of the remote St. Peter and St. Paul's Archipelago, MidAtlantic Ridge, Brazil. Coral Reefs 35

Roseli NM, Akhir MF, Husain ML, Tangang F, Ali A. 2015. Water mass characteristics and stratification at the shallow Sunda Shelf of Southern South China Sea. Open Journal of Marine Science Vol. 5 : 455-467

Rosenfield D, Kamenkovich V, O'Driscoll K and Sprintall J. 2010. Validation of a regional Indonesian sea model based on a comparison between model and INSTANT transports. J. Dynamic of Atmospheres and Oceans Vol. $50: 313-330$

Rusydi AF. 2018. Correlation between conductivity and total dissolved Solids in various type of water: a review. IOP Conf. Ser.: Earth Environ. Sci. Vol. 118 : 6 pages

Sahid. 2005. Pengantar Komputasi Numerik dengan MATLAB. Yogyakarta : C.V Andi Offset

Santos-Garcia A, Jacob MM, Jones WL, Asher WE, Hejazin Y,Ebrahimi E, Rabolli M. 2014. Investigation of rain effects on Aquarius sea surface salinity measurements. J. Geophys. Res. Oceans Vol. 119 : 7605-7624

Sidabutar HC, Rifai A, Indrayanti E. 2014. Kajian Lapisan Termoklin di Perairan Utara Jayapura. Jurnal Oseanografi 3 (2) : 135-141

Sigman DM. 2010. The polar ocean and glacial cycles in atmospheric CO2 concentration. Nature Vol. $466: 47-55$

Soewarno, 1995, Hidrologi (Aplikasi Metode Statistik untuk Analisis Data jilid I). Bandung : Nova

Stewart RH. 2009. Introduction to Physical Oseanography. Texas (USA) : Department of Oceanography, Texas A \& M University. 312 pages 
Sudjana, 1992. Metode Statistika. Edisi ke 5. Bandung: Penerbit Tarsito. $75 \mathrm{hlm}$

Sugiyono. 2008. Statistika untuk Penelitian. Bandung: Alfabeta

Susanto RD, Gordon AL, Sprintall J. 2007. Observations and Proxies of the Surface Layer Throughflow in Lombok Strait. J. Geophysical Research Vol. 112 (C03S92) : 1-11

Susanto RD, Mitnik L, Zheng Q. 2005. Ocean internal waves observed in the Lombok Strait. Oceanogr Journal Vol. 18(4) : 80-87

Suteja Y, Purba M, Atmadipoera AS. 2015. Percampuran turbulen di Selat Ombai. Jurnal Ilmu dan Teknologi Kelautan Tropis Vol. 7 (1) : 71-82

Tanaka A, Okubo Y, Matsubayashi O. 1999. Curie point depth based on spectrum analysis of the magnetic anomaly data in East and Southeast Asia. Tectonophysics Vol. $306: 461-470$

Tang CL, D'Alessio SJD, DeTracey BM. 2006. Mixed-layer simulations at OWS Bravo: the role of salinity in interannual variability of the upper ocean at high latitude. International Journal of Oceans and Oceanography Vol. 1(1) : 119-139. ISSN 0973-2667

Theoyana TA, Pranowo WS, Anastasia RTDK, Purwanto. 2015. Karakteristik arus pasang surut di Selat Badung, Bali. J. Segara Vol. 11 (2) : 115-123

Thompson K. 2006. AWWA Research Foundation, WateReuse Foundation, \& Water Quality Association. Characterizing and Managing Salinity Loadings in Reclaimed Water Systems. USA : American Water Works Association.

Tjondro I, Tanti Y. 2009. Pendayagunaan linear air track untuk percobaan gerak lurus beraturan dan gerak lurus berubah beraturan. Magister Scientiae Ed. 26 : 98-122. ISSN 0852-078x

Tomczak M. 2000. Lecture Notes in Oceanography. Australia : School of Chemistry, Physics \& Earth Sciences. 123 pages

Triatmodjo B. 2006. Hidrologi Terapan. Yogyakarta : Beta Offset. 355 hlm. In : Nurjaya IW, Surbakti H. 2009. Studi pendahuluan kondisi oseanografi fisik pada musim barat di perairan Pantai Timur Kalimantan antara Balikpapan dan Delta Mahakam. Jurnal Kelautan Nasional Vol. 1 : 140-150

Turak E, DeVantier LM. 2009. Biodiversity and Conservation Priorities of Reef-building Corals in Nusa Penida. Denpasar : Conservation International Indonesia

Wagner RJ, Boulger J, Oblinger RW, Smith BA. 2006. Guidelines and Standard Procedures for Continuous Water-Quality Monitors: Station Operation, Record Computation, and Data Reporting. USA : USGS Techniques and Methods

Wajsowicz RC, Schneider EK. 2001. The Indonesian throughflow's effect on global climate determined from the COLA coupled climate system. J. Clim Vol. 14 : 3029-3042

Walton NRG. 1989. Electrical conductivity and total dissolved Solids what is their precise relationship? Desalination Vol. 72 (3) : 275-292

Weber-Scannell PK, Duffy LK. 2007. Effect of total dissolved Solids on aquatic organisms: a review of literature and rrecommendation for Salmonid Species. American Journal of Environmental Sciences Vol. $3(1): 1-6$

Weidemann AD, Pegau WS, Jugan LA, Bowers TE. 1996. Tidal influences on optical variability in shallow water. Ocean Optics Journal Vol. $2963: 320-325$

WHO. 2003. Total dissolved Solids in Drinkingwater. Geneva Switzerland : World Health Organization 